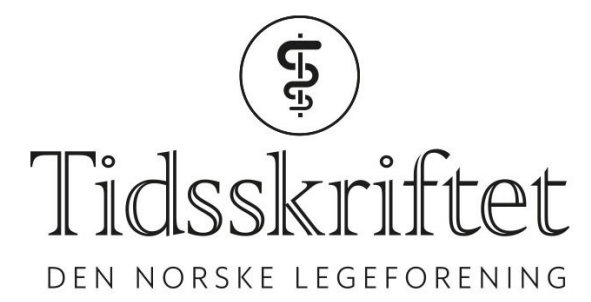

\title{
Ernæringsstatus av vitamin og sporelement
}

FRA LABORATORIET

\section{PAUL KJETEL SOLDAL LILLEMOEN}

Paul Kjetel Soldal Lillemoen er lege i spesialisering i medisinsk biokjemi ved Avdeling for medisinsk biokjemi og farmakologi ved Haukeland universitetssjukehus.

Forfattaren har fylt ut ICMJE-skjemaet og oppgir ingen interessekonfliktar.

\section{ANNE-LISE BJØRKE-MONSEN}

E-post:almo@helse-bergen.no

Anne-Lise Bjørke-Monsen er spesialist i barnesjukdommar og i medisinsk biokjemi, overlege ved Avdeling for medisinsk biokjemi og farmakologi ved Haukeland universitetssjukehus og førsteamanuensis ved Klinisk institutt 2 ved Universitetet i Bergen. Ho er styremedlem i Norsk selskap for medisinsk biokjemi.

Forfattaren har fylt ut ICMJE-skjemaet og oppgir ingen interessekonfliktar.

Underernæring og feilernæring er vanleg hos sjuke og eldre, men førekjem også i svangerskap, i vekstperiodar og ved einsidig diett. For å sikra optimal vitamin- og sporelementstatus er det viktig med rett diagnostikk.

Mikronæringsstoffa er essensielle substansar som me treng å få tilført i små mengder for normal kroppsfunksjon. Mikronæringsstoffa omfattar ni vassløyselege vitamin (vitamin B1, B2, B3, B5, B6, B7, B9, B12 og C), fire feittløyselege vitamin (vitamin A, D, E og K), jern og sporelement som jod, kopar, krom, mangan, molybden, selen og sink. Vitamina er antioksidantar, prohormon eller kofaktorar i metabolske reaksjonar, medan sporelementa er katalytiske eller strukturelle komponentar i organiske molekyl. Mangel på mikronæringsstoff kan i ytste fall gje livstrugande tilstandar som beriberi (mangel på vitamin B1), pellagra (vitamin B3) og skjørbuk (vitamin C). På verdsbasis er mangel på til dømes jern, jod, sink og vitamin A svært utbreidd og assosiert med auka barnedødelegheit, anemi, redusert psykomotorisk utvikling, veksthemming, redusert infeksjonsforsvar og blindheit (1). Medan uttalte mangeltilstandar er uomstridde, er det generelt stor usemje om konsekvensane av mindre uttalt eller subklinisk mangel $(2,3)$.

\section{Referanseområde}

Dei fleste mikronæringsstoffa og fleire metabolske markørar kan målast i blod eller urin, men tolkinga er ofte problematisk. I medisinsk biokjemi brukar me ofte referanseområde, som skal vera dei sentrale $95 \%$ av analyseresultata i ei frisk befolkning. Referanseområde kan etablerast for ulike kjønn og aldersgrupper og egnar seg godt til å vurdera endogene biokjemiske parametrar som kreatinin og albumin. Referanseområda for mikronæringsstoff avheng derimot av ytre faktorar som jordsmonn, solstråling og 
kosthaldet i befolkninga referanseområdet er basert på. Til dømes er referanseområdet for serumfolat (vitamin B9) 5-29 nmol/l i Noreg, medan det er 16-109 nmol/l i USA, der ein tilset folinsyre i mjølet $(4,5)$. Eit anna døme er vitamin B12, der konsentrasjonen i serum reflekterer inntaket av animalske matvarer. Med andre ord vil eit lågt folatnivå i USA vera $\mathrm{i}$ normalområdet i Noreg, medan eit lågt vitamin B12-nivå i Noreg vil vera i normalområdet $\mathrm{i}$ India $(3,5)$.

\section{Aksjonsgrenser}

Referanseområda skildrar vitamin- og sporelementnivået i befolkninga, men fortel altså ikkje kva som er adekvat eller optimal status. Til det bør ein heller bruka aksjonsgrenser, også kjent som kliniske beslutningsgrenser. Tradisjonelt er aksjonsgrensene basert på tydelege teikn på tomme lager, men det er aukande forståing for at også subklinisk mangel kan svekka helsa (6). Det er til dømes dårleg medisinsk praksis å venta med intervensjon til jernmangel har ført til mikrocytær anemi. Me meiner at det bør brukast diagnostikk og aksjonsgrenser som sikrar optimal vitamin- og sporelementstatus.

Utfordringa er å finna gode biomarkørar og aksjonsgrenser. Me brukar her vurdering av jernstatus som eit døme, men prinsippa kan også gjelda for andre mikronæringsstoff.

For diagnostikk av jernstatus bør ein måla serumferritin, serumløyseleg transferrinreseptor eller retikulocytthemoglobin. Hos barn er serumferritinnivå mellom 5 og $20 \mu \mathrm{g} / \mathrm{l}$ brukt som aksjonsgrenser for jernmangel, men fleire hematologiske parametrar vert først stabiliserte ved serumferritin over $30 \mu \mathrm{g} / \mathrm{l}$ ved alder under 13 år og ved serumferritin over $40 \mu \mathrm{g} / \mathrm{l}$ ved alder mellom 13 og 19 år (7). Når me veit at jern ikkje berre er viktig for hemoglobinnivået, men også for normal psykomotorisk utvikling og funksjon (8), bør me vurdera å setta aksjonsgrensene for låge serumferritinverdiar høgare enn i dag.

\section{LITTERATUR:}

1. Bailey RL, West KP, Black RE. The epidemiology of global micronutrient deficiencies. Ann Nutr Metab 2015; 66 (suppl 2): 22-33. [PubMed][CrossRef]

2. Carleen MH, Weissman N, Owen PS et al. Subclinical vitamin deficiency. Science 1943; 97: 47-9. [PubMed][CrossRef]

3. Sivaprasad M, Shalini T, Reddy PY et al. Prevalence of vitamin deficiencies in an apparently healthy urban adult population: Assessed by subclinical status and dietary intakes. Nutrition 2019; 63-64: 106-13. [PubMed][CrossRef]

4. Pfeiffer CM, Sternberg MR, Fazili Z et al. Folate status and concentrations of serum folate forms in the US population: National Health and Nutrition Examination Survey 2011-2. Br J Nutr 2015; 113: 1965-77. [PubMed][CrossRef]

5. Schwettmann L, Berbu S. Reference interval and status for serum folate and serum vitamin B12 in a Norwegian population. Clin Lab 2015; 61:1095-100. [PubMed][CrossRef]

6. Houston MC. The role of cellular micronutrient analysis, nutraceuticals, vitamins, antioxidants and minerals in the prevention and treatment of hypertension and cardiovascular disease. Ther Adv Cardiovasc Dis 2010; 4: 165-83. [PubMed][CrossRef]

7. Markus C, Saxon B, Metz M. Ferritin as a functional biomarker of iron status in children and young adults. Br J Haematol 2019; 184: 640-2. [PubMed][CrossRef]

8. Barks A, Hall AM, Tran PV et al. Iron as a model nutrient for understanding the nutritional origins of neuropsychiatric disease. Pediatr Res 2019; 85:176-82. [PubMed][CrossRef]

Publisert:30. mars 2020. Tidsskr Nor Legeforen. DOI: 10.4045/tidsskr.19.0587

(C) Tidsskrift for Den norske legeforening 2020. Lastet ned fra tidsskriftet.no 